\author{
동계사료작물 사일리지를 첨가한 $\mathrm{TMR}$ 급여가 흑염소의 \\ 사료섭취량, 영양소 소화율 및 혈액성상에 미치는 영향 \\ 정기웅 · 조익환 · 황보순* · 이성훈**
}

\title{
Effects of Feeding Total Mixed Rations Containing Different Winter Forage Crop Silages on Feed Intake, Nutrient Digestibility and Blood Characteristics in Korean Black Goats
}

Gi Woung Jung, Ik Hwan Jo, Soon Hwangbo* and Sung Hoon Lee**

\begin{abstract}
This study was conducted to determine the feed value of total mixed rations (TMR) containing different winter forage crop silages on feed intakes, daily gain, nutrient digestibility, and nitrogen retention in Korean black goats. A total of 12 male goats were used in this study and each goat was housed in individual metabolism crates. The treatments were four diets, consisting of whole crop barley silage (T1), rape silage (T2), rye silage (T3), and Italian ryegrass silage (T4). The experiment was designed as a $4 \times 4$ Latin square arrangement in three replicates. Daily intakes for dietary dry matter(DM), organic matter $(\mathrm{OM})$, crude protein $(\mathrm{CP})$ per head were highest in rape silage treatment, and lowest in whole barley silage $(p<0.05)$. Digestible intakes for $C P$ and acid detergent fiber were highest in rape silage treatment. The daily gain of rape, rye, and Italian ryegrass silages were significantly $(\mathrm{p}<0.05)$ higher than that of whole crop barley silage. Digestibility of DM. CP, fiber were highest in whole crop barley silage, and lowest in rape silage $(\mathrm{p}<0.05)$. Nitrogen $(\mathrm{N})$ intake and $\mathrm{N}$ retention were significantly highest in rape silage and lowest in whole crop barley silage $(\mathrm{p}<0.05)$. The results showed that, among different winter forage crop silages, rape silage incorporation into TMR had the best performances indicating increases of feed intakes and $\mathrm{N}$ retention in Korean black goats.
\end{abstract}

(Key words : Winter forage crop silage, Total mixed rations, Nutrient digestibility, Nitrogen retention, Korean black goats)

$$
\text { I. 서 론 }
$$

최근 소비자의 건강식품 선호로 인해 흑염소 의 소비가 증가되어 사육형태가 부업의 소규모 에서 점차 전업화로 변화되고 있으며, 소비 형
태도 중탕 위주의 약용에서 육용위주로 소비가 크게 증가되고 있다. 그러나 근래 국제 곡물가 격 상승과 고유가로 국내 배합사료 가격이 급 등하여 흑염소 사육 농가의 어려움이 가중되고 있어 생산비 절감을 위한 다각적인 자구책이

대구대학교 (Daegu University, Gyeongsan, 712-714, Korea)

* 국립축산과학원 (National Institute of Animal Science, RDA, Cheonan 331-808, Korea)

** 경상남도축산진흥연구소 (Gyeongsangnamdo Livestock Promotion Research Institute, Sancheong 666-962, Korea)

Corresponding author : Ik-Hwan Jo, Fax:+82-53-850-6729, Tel:+82-53-850-6725, E-mail: greunld@deagu.ac.kr 
강구되고 있다.

가축생산비 절감을 위한 국내 자급 조사료의 확보 방안으로 겨울철 논을 이용한 청보리, 이 탈리안 라이그라스 및 호밀 등과 같은 동계사 료작물의 재배 및 이용에 대한 연구가 활발히 수행되고 있다(김과 서, 2006; 김 등, 2007b; 조 등, 2008). 동계사료 작물의 재배면적 또한 정부의 겨울철 유휴농지를 활용한 조사료 생산 기반 확충에 따라 급증하는 추세이다.

또한, 동계사료 작물에 대한 흑염소 급여 효 과의 연구에서, 김 등 (2007a)은 청보리 사일리 지를 TMR 사료로 조제하여 흑염소에게 급여 하였을 때 혈액 성상이 개선되었고, 청보리 사 일리지 급여는 볏짚 보다 농후사료 절감 및 발 육개선의 효과가 있었다(황보 등, 2008)고 하 여 동계사료 작물의 급여는 가축의 생산성을 향상시키는 것으로 보고되고 있다.

한편, 흑염소 농가는 산육성 증대를 위해 농 후사료 다급과 함께 조사료원으로는 볏짚을 분 리 급여하여 사료비 상승요인 뿐만이 아니라 대사성 질병, 반추위 발효성상 저하 등 많은 문제점이 대두되고 있다(송 등, 1999). 이러한 사료급여체계의 문제 해결을 위해 완전혼합섬 유질사료 (TMR: total mixed ration) 급여는 흑 염소의 영양소 요구량을 충족시킴과 동시에 위 내 미생물을 이상적으로 유지시켜 줌으로써 최 상의 반추위 소화생리 작용을 도모하여 (Nocek 등, 1985), 흑염소의 생산성 향상을 유도할 수 있다 (정 등, 2008).

따라서, 본 연구에서는 동계사료작물 사일리 지를 첨가한 $\mathrm{TMR}$ 을 급여하였을 때, 흑염소의 사료 섭취량, 일당 증체량, 영양소 소화율, 질 소 축적율 및 혈액성상에 미치는 영향을 조사 하여 흑염소에 대한 동계사료작물의 사료가치 평가 자료로 이용하고자 실시하였다.

\section{ㅍ. 재료 및 방법}

\section{1. 공시 가축 및 사양관리}

본 시험의 공시가축은 평균체중이 $16 \mathrm{~kg}$ 내외 인 재래흑염소 12 두(옹)를 개체별 대사 케이지 에 수용하여 시험사료를 1일 2회 (07:00, 17:00) 급여하였고, 물은 자유 급수하여 충분히 음수 토록 하였다.

\section{2. 시험설계 및 시험사료}

본 시험의 처리는 동계사료작물 사일리지 첨 가 (T1: 청보리 사일리지 첨가구, $\mathrm{T} 2$ : 유채 사 일리지 첨가구, $\mathrm{T} 3$ : 호밀 사일리지 첨가구 및 $\mathrm{T} 4$ : 이탈리안 라이그라스 사일리지 첨가구)에 따른 4 처리구로 나누어 처리구당 3 두씩 개체별 대사케이지에 라틴방각법으로 실시하였고, 사 료적응기간 14 일과 예비기간 10 일을 거친 후, 10 일간의 본 시험기간 동안 사료섭취량 및 분 · 뇨 배설량을 측정하였다.

시험사료의 배합비와 화학적 조성분은 Table 1 과 같으며, 시험사료는 완전혼합섬유질사료 (TMR: total mixed rations)로 배합하여 급여하 였다.

\section{3. 조사항목 및 분석방법}

\section{(1) 사료섭취량}

사료섭취량은 급여한 사료와 섭취하고 남은 사료의 차이로 구하였으며, 잔량은 다음날 오전 사료를 급여하기 전에 수거하여 측정하 였다.

(2) 분과 뇨의 채취 및 화학적 분석

분은 본 실험기간 동안 매일 총 배설량을 칭 량하고 수거한 분을 잘 혼합한 후 이 중 $10 \%$ 를 채취하여 $60^{\circ} \mathrm{C}$ 건조기에서 48 시간 건조한 후 중량을 측정, 환산하였으며 이들 일부는 Wiley mill의 $40 \mathrm{mesh}$ 에서 분쇄하여 분석시료로 사용하였고, 뇨는 매일 용기에 $5 \mathrm{~N} \mathrm{HCl}$ 을 투입 하여 1 일 배설량을 측정하고 이 중 $10 \%$ 를 채 
Table 1. Ingredients and chemical compositions of experimental diets fed to Korean black goats

\begin{tabular}{|c|c|c|c|c|}
\hline \multirow{2}{*}{ Ingredients } & \multicolumn{4}{|c|}{ Treatments } \\
\hline & $\mathrm{T} 1$ & $\mathrm{~T} 2$ & $\mathrm{~T} 3$ & $\mathrm{~T} 4$ \\
\hline \multicolumn{5}{|l|}{ Ingredients (\%) } \\
\hline Whole crop barley silage & 40 & - & - & - \\
\hline Rape silage & - & 40 & - & - \\
\hline Rye silage & - & - & 36 & - \\
\hline Italian ryegrass silage & - & - & - & 40 \\
\hline Corn gluten feed & 21 & 18 & 15 & 15 \\
\hline Wheat bran & 11 & 10 & 4 & 15 \\
\hline Wheat & 7 & 9 & 20 & 8 \\
\hline Yellow corn & 7 & 9 & 10 & 9 \\
\hline Soybean meal & 14 & 14 & 15 & 13 \\
\hline Total & 100 & 100 & 100 & 100 \\
\hline \multicolumn{5}{|l|}{ Chemical composition $(\%)$} \\
\hline Moisture & 35.30 & 35.25 & 35.50 & 35.40 \\
\hline Crude protein & 15.11 & 15.17 & 15.03 & 15.27 \\
\hline $\mathrm{ADF}$ & 20.48 & 25.12 & 23.53 & 20.04 \\
\hline $\mathrm{NDF}$ & 39.92 & 39.62 & 40.23 & 39.98 \\
\hline Crude ash & 6.72 & 6.75 & 8.63 & 6.32 \\
\hline Ether extracts & 4.99 & 5.77 & 4.12 & 5.38 \\
\hline Non-fibrous carbohydrate & 33.26 & 32.69 & 31.99 & 33.05 \\
\hline
\end{tabular}

취하여, 뇨 중 질소분석시까지 $-20^{\circ} \mathrm{C}$ 냉동고 1650, Bayer, Japan)로 하였고, 혈장내 요소태질 에 보관하였다. 시료의 일반성분은 $\mathrm{AOAC}$ 소(PUN: plasma urea nitrogen)는 Urease with (1995)법에 따라 분석하였고, $\mathrm{ADF}$ 및 $\mathrm{NDF}$ 는 $\mathrm{GLDH}$ (ADVIA 1650, Bayer, Japan)를 사용하여 Van Soest 등 (1991)의 방법에 따라 분석하였다. 분석하였다. Cholesterol은 emzymatic, colorimetry 법 (ADVIA 1650, Bayer, Japan)을 이용하여 분 (3) 혈액의 채취 및 분석방법 혈액채취는 본 시험 마지막 날 경정맥에서 석하였고, LDL cholesterol은 Emzymatic colorimetry (Hitachi 7180, Hitachi. Japan)를 이용하여 vacutainer로 $10 \mathrm{ml}$ 채혈한 후 원심분리하여 분석하였으며, $\mathrm{HDL}$ 은 cholesterol에서 $\mathrm{LDL}$ $(3,000 \mathrm{rpm} / 10$ 분 $)$ 상층액을 채취하여 분석시까지 $-20^{\circ} \mathrm{C}$ 에서 냉동보관 하였다.

cholesterol을 감하여 계산하였고, Triglyceride는

Glucose의 분석은 enzymatic method (ADVIA

Lipase, GK, GPD, colorimetry (ADVIA 1650, Bayer, Japan)에 의하여 분석하였다. 


\section{4. 통계분석}

본 실험의 결과는 SAS package program (version 8.2, USA, 2000)으로 분산분석 후 처리 간 유의성 검정을 위해 Duncan's multiple range test $(5 \%$ 수준)를 이용하였다 (Steel과 Torrie, 1980).

\section{III. 결과 및 고찰}

1. 시험사료의 영양소 및 가소화 영양소 섭 취량

동계사료작물 사일리지 첨가 $\mathrm{TMR}$ 을 흑염소 에게 급여시 시험사료의 영양소 및 가소화 영 양소 섭취량에 미치는 영향은 Table 2와 같다.

Table 2. The effect of TMR containing different winter forage crops silage on nutrient intake, digestible nutrient intake and body gain in Korean black goats

\begin{tabular}{|c|c|c|c|c|c|}
\hline \multirow{2}{*}{ Items } & \multicolumn{4}{|c|}{ Treatments $^{1)}$} & \multirow{2}{*}{$\mathrm{SEM}^{2}$} \\
\hline & $\mathrm{T} 1$ & $\mathrm{~T} 2$ & $\mathrm{~T} 3$ & $\mathrm{~T} 4$ & \\
\hline \multicolumn{6}{|l|}{ Intake $(\mathrm{g} / \mathrm{d})$} \\
\hline Dry matter & $330.7^{\mathrm{b}}$ & $503.9^{\mathrm{a}}$ & $439.1^{\mathrm{ab}}$ & $418.7^{\mathrm{ab}}$ & 73.27 \\
\hline Organic matter & $308.5^{\mathrm{b}}$ & $469.9^{\mathrm{a}}$ & $401.2^{\mathrm{ab}}$ & $392.3^{\mathrm{ab}}$ & 67.60 \\
\hline Crude protein & $49.97^{b}$ & $76.44^{\mathrm{a}}$ & $65.99^{\mathrm{ab}}$ & $63.94^{\mathrm{ab}}$ & 11.08 \\
\hline $\mathrm{ADF}$ & $67.73^{\mathrm{c}}$ & $126.57^{\mathrm{a}}$ & $103.3^{\mathrm{ab}}$ & $83.93^{\mathrm{bc}}$ & 16.51 \\
\hline NDF & $132.1^{\mathrm{b}}$ & $199.7^{\mathrm{a}}$ & $176.7^{\mathrm{ab}}$ & $167.4^{\mathrm{ab}}$ & 29.36 \\
\hline Ether extracts & $16.50^{\mathrm{b}}$ & $29.08^{\mathrm{a}}$ & $18.09^{\mathrm{b}}$ & $22.53^{b}$ & 3.44 \\
\hline $\mathrm{NFC}$ & $110.0^{\mathrm{b}}$ & $164.7^{\mathrm{a}}$ & $140.5^{\mathrm{ab}}$ & $138.4^{\mathrm{ab}}$ & 23.75 \\
\hline \multicolumn{6}{|l|}{ Digestible nutrient Intake (g/d) } \\
\hline Dry matter & 233.6 & 336.6 & 297.6 & 290.1 & 53.76 \\
\hline Organic matter & 223.4 & 319.3 & 281.7 & 280.4 & 51.95 \\
\hline Crude protein & $35.35^{\mathrm{b}}$ & $52.22^{\mathrm{a}}$ & $45.60^{\mathrm{ab}}$ & $44.62^{\mathrm{ab}}$ & 7.79 \\
\hline $\mathrm{ADF}$ & $37.84^{\mathrm{b}}$ & $57.40^{\mathrm{a}}$ & $49.50^{\mathrm{ab}}$ & $43.69^{\mathrm{ab}}$ & 7.97 \\
\hline NDF & 76.40 & 99.57 & 96.60 & 92.43 & 16.72 \\
\hline Ether extracts & $13.51^{b}$ & $22.14^{\mathrm{a}}$ & $14.22^{\mathrm{b}}$ & $18.39^{\mathrm{ab}}$ & 3.29 \\
\hline NFC & 98.20 & 145.3 & 125.9 & 124.9 & 25.08 \\
\hline DM Intake, $\mathrm{g} / \mathrm{kg}$ of $\mathrm{BW}^{0.75}$ & $42.88^{\mathrm{b}}$ & $62.56^{\mathrm{a}}$ & $54.42^{\mathrm{ab}}$ & $51.71^{\mathrm{ab}}$ & 6.20 \\
\hline DM Intake/BW(\%) & $2.17^{\mathrm{c}}$ & $3.12^{\mathrm{a}}$ & $2.72^{\mathrm{ab}}$ & $2.58^{\mathrm{bc}}$ & 0.28 \\
\hline Average daily gain (g/day) & $50.67^{\mathrm{b}}$ & $64.00^{\mathrm{a}}$ & $60.00^{\mathrm{a}}$ & $59.33^{\mathrm{a}}$ & 3.93 \\
\hline
\end{tabular}

1) T1: TMR containing whole crop barley silage, T2: TMR containing rape silage,

T3: TMR containing rye silage, T4: TMR containing italian ryegrass silage.

2) Standard error of the mean.

a, b, c Means in a row with different superscripts are significantly different $(\mathrm{p}<0.05)$. 
1 일 두당 건물과 유기물 섭취량은 유채 사일 리지 첨가구가 각각 503.9 와 $469.9 \mathrm{~g}$ 으로 청보리 사일리지 첨가구의 각각 330.7 과 $308.5 \mathrm{~g}$ 보다 유의하게 높았으며 $(\mathrm{p}<0.05)$, 조단백질 섭취량에 서도 유채 사일리지 첨가구가 $76.4 \mathrm{~g}$ 으로 가장 높았다 $(\mathrm{p}<0.05) . \mathrm{ADF}$ 와 $\mathrm{NDF}$ 섭취량은 유채 사일리지 첨가구 $>$ 호밀 사일리지 첨가구 $>$ 이 탈리안 라이그라스 사일리지 첨가구>청보리 사일리지 첨가구 순으로 나타났으며 에테르 추 출물 섭취량은 유채 사일리지 첨가구가 다른 시험구에 비해 $29.0 \mathrm{~g}$ 으로 유의하게 높았다 $(\mathrm{p}<0.05)$.

1 일 가소화 건물과 유기물 섭취량은 각각 233.6 336.6과 $223.4 \sim 319.3 \mathrm{~g}$ 으로 시험구간에 유의성은 나타나지 않았지만 유채 사일리지 첨 가구가 높고 청보리 사일리지 첨가구가 낮은 경향으로 나타났다. 가소화 조단백질 섭취량은 유채 사일리지 첨가구가 $52.2 \mathrm{~g}$ 으로 각각 45.6 과 $44.6 \mathrm{~g}$ 을 섭취한 호밀과 이탈리안 라이그라스 사일리지 첨가구와 유의적인 차이는 나타나지 않았으나 $35.3 \mathrm{~g}$ 을 섭취한 청보리 사일리지 첨 가구와는 유의적인 차이가 나타났다 $(\mathrm{p}<0.05)$. 가소화 $\mathrm{ADF}$ 섭취량은 유채 사일리지 첨가구가 $57.4 \mathrm{~g}$ 으로 가장 높았고 $(\mathrm{p}<0.05)$, 가소화 $\mathrm{NDF}$ 와 $\mathrm{NFC}$ 섭취량은 각각 $76.4 \sim 99.5$ 와 $98.2 \sim 145.3 \mathrm{~g}$ 으로 시험구간 유의적인 차이는 나타나지 않았 지만 유채 사일리지 첨가구가 높은 경향으로 나타났다.

대사체중당 건물섭취량과 체중에 대한 건물 섭취비율은 유채 사일리지 첨가구가 각각 $62.5 \mathrm{~g}$ 과 $3.12 \%$ 로 청보리 사일리지 첨가구의 각 각 $42.8 \mathrm{~g}$ 과 $2.17 \%$ 보다 유의하게 높았다 ( $\mathrm{p}<$ 0.05).

1일 두당 증체량은 유채, 호밀 및 이탈리안 라이그라스 사일리지 첨가구가 $59.3 \sim 64 \mathrm{~g}$ 으로 청보리 사일리지 첨가구의 $50.6 \mathrm{~g}$ 보다 유의하 게 높게 나타났다 $(\mathrm{p}<0.05)$.
유채는 화본과 사료작물에 비해 사료가치가 우수하고 기호성이 높은 것으로 알려져 왔다 (Barnes 등, 1995). 청예사료작물을 첨가한 완전 배합발효사료를 면양 (이 등, 2002)과 Holstein (이 등, 2003)에게 급여 시 유채 첨가구가 높은 섭취량을 보여 유채의 기호성이 뛰어남을 보고 하여 본 시험의 결과와 일치하는 것으로 나타 났다.

한편, 단백질은 가축의 성장과 발육에 꼭 필 요한 영양소로 체중 $20 \mathrm{~kg}$ 인 흑염소의 유지를 위한 1 일 총단백질과 가소화 조단백질은 각각 38 과 $26 \mathrm{~g}$ 이며, 유지 (중활동)와 일당 증체량 50 $\mathrm{g}$ 을 충족시키기 위한 총단백질과 가소화 조단 백질은 각각 69와 $48 \mathrm{~g}$ 이 요구된다 (NRC, 1981). 본 시험에서 청보리 사일리지 첨가구의 총단백 질과 가소화 조단백질 섭취량은 각각 50.0 과 $35.4 \mathrm{~g}$ 으로 일당 $50 \mathrm{~g}$ 증체를 위한 수준에는 미 치지 못하였으나, 호밀과 이탈리안 라이그라스 사일리지 첨가구는 비슷한 수준이었고, 유채 사일리지 첨가구는 충분한 것으로 나타났다. 유채 사일리지 첨가구의 높은 단백질 섭취량은 기호성이 우수하여 건물 섭취량의 증가에 따른 결과라 사료된다.

\section{2. 영양소 소화율}

동계사료작물 사일리지 첨가 $\mathrm{TMR}$ 을 흑염소 에게 급여시 영양소 소화율에 미치는 영향은 Table 3 과 같다.

건물과 유기물 소화율은 청보리 사일리지 첨 가구가 각각 70.6 과 $72.4 \%$ 로 유채 사일리지 첨 가구의 각각 66.7 과 $67.8 \%$ 보다 유의하게 높았 으며 $(\mathrm{p}<0.05)$, 조단백질 소화율 또한 청보리 사 일리지 첨가구가 $70.4 \%$ 로 유채 및 호밀 사일리 지 첨가구의 각각 68.2 와 $69.0 \%$ 보다 유의하게 높은 수준이었다 $(\mathrm{p}<0.05) . \mathrm{ADF}$ 소화율은 청보 리와 이탈리안 라이그라스 사일리지 첨가구가 
Table 3. The effect of TMR containing different winter forage crops silage on nutrient digestibility in Korean black goats

\begin{tabular}{lccccc}
\hline \multirow{2}{*}{ Items } & \multicolumn{4}{c}{ Treatments $^{1)}$} & \multirow{2}{*}{ SEM $^{2)}$} \\
\cline { 2 - 5 } & $\mathrm{T} 1$ & $\mathrm{~T} 2$ & $\mathrm{~T} 3$ & $\mathrm{~T} 4$ & \\
\hline \hline Dry matter & $70.64^{\mathrm{a}}$ & $66.73^{\mathrm{b}}$ & $67.72^{\mathrm{b}}$ & $69.07^{\mathrm{ab}}$ & 1.38 \\
Organic matter & $72.41^{\mathrm{a}}$ & $67.86^{\mathrm{b}}$ & $70.13^{\mathrm{ab}}$ & $71.22^{\mathrm{a}}$ & 1.63 \\
Crude protein & $70.74^{\mathrm{a}}$ & $68.26^{\mathrm{b}}$ & $69.08^{\mathrm{b}}$ & $69.79^{\mathrm{ab}}$ & 0.79 \\
ADF & $55.93^{\mathrm{a}}$ & $45.30^{\mathrm{b}}$ & $47.99^{\mathrm{b}}$ & $52.06^{\mathrm{a}}$ & 2.09 \\
NDF & $57.91^{\mathrm{a}}$ & $49.77^{\mathrm{b}}$ & $54.82^{\mathrm{a}}$ & $55.06^{\mathrm{a}}$ & 2.33 \\
Ether extracts & 81.84 & 76.05 & 78.78 & 80.91 & 3.51 \\
NFC & 89.14 & 88.16 & 89.21 & 89.85 & 5.60 \\
\hline
\end{tabular}

1) T1: TMR containing whole crop barley silage, T2: TMR containing rape silage,

T3: TMR containing rye silage, T4: TMR containing italian ryegrass silage.

2) Standard error of the mean.

${ }^{\mathrm{a}, \mathrm{b}}$ Means in a row with different superscripts are significantly different $(\mathrm{p}<0.05)$.

각각 55.9 와 $52.0 \%$ 로 다른 시험구 보다 유의하 게 높았으며 $(\mathrm{p}<0.05), \mathrm{NDF}$ 소화율은 유채 사일 리지 첨가구가 $49.7 \%$ 로 가장 낮았다 $(\mathrm{p}<0.05)$. 에테르 추출물과 $\mathrm{NFC}$ 소화율은 각각 76.0 81.8 과 $88.1 \sim 89.8 \%$ 의 범위로 시험구간 유의성 은 나타나지 않았다.

본 시험에서 청보리 사일리지 첨가구의 유기 물 소화율은 $72.4 \%$ 로, 청보리 사일리지를 30 과 $60 \%$ 첨가한 $\mathrm{TMR}$ 급여시 흑염소의 유기물 소 화율이 64.5 와 $74.7 \%$ 라고 보고(김 등, 2007a) 한 범위와 유사하였으며, 이탈리안 라이그라스 를 일본 재래 염소에게 급여시 $66.1 \sim 76.6 \%$ 의 범위의 유기물 소화율을 보였다(Islam 등, 2000)고 하여 본 시험의 결과와 일치하였다.

건물과 유기물 소화율은 유채 사일리지 첨가 구가 청보리 사일리지 첨가구 보다 유의하게 낮았는데 $(\mathrm{p}<0.05)$, 이는 사료섭취량의 증가에 따른 반추위 내 통과 속도가 빨라져 소화율이 감소된 것으로 판단된다. 이와 같은 결과는 사 료섭취량이 높을수록 장관내 사료가 채류하는
시간이 짧아지는 경우에는 사료 분해율을 감소 시킴으로써 사료 섭취량과 소화율은 부의 상관 관계를 보여준다고 한 Huston 등 (1986)과 Van Soest (1994)의 시험의 결과와 일치하였다. 또 한, $\mathrm{ADF}$ 함량은 소화율에서 중요한 요인으로 작용하는데 (Van Soest, 1994), 본 시험에서 유 채와 호밀 사일리지 첨가구의 낮은 소화율은 시험사료의 높은 $\mathrm{ADF}$ 함량 (Table 1)에 기인한 것으로 사료된다.

\section{3. 질소축적}

동계사료작물 사일리지 첨가 $\mathrm{TMR}$ 을 흑염소 에게 급여시 질소축적에 미치는 영향은 Table 4 와 같다.

질소섭취는 $8.00 \sim 12.23 \mathrm{~g}$ 의 범위로 유채 사 일리지 첨가구가 청보리 사일리지 첨가구 보다 유의하게 높은 섭취를 보였으며 $(\mathrm{p}<0.05)$, 분을 통한 배출 질소량도 이와 같은 경향으로 유채 사일리지 첨가구가 $3.87 \mathrm{~g}$ 으로 청보리 사일리 
Table 4. The effect of TMR containing different winter forage crops silage on the nitrogen retention in Korean black goats

\begin{tabular}{lccccc}
\hline \multirow{2}{*}{ Items } & \multicolumn{4}{c}{ Treatments $^{1)}$} & \multirow{2}{*}{ SEM $^{2)}$} \\
\cline { 2 - 4 } & $\mathrm{T} 1$ & $\mathrm{~T} 2$ & $\mathrm{~T} 3$ & $\mathrm{~T} 4$ & \\
\hline \hline Total N intake (g/day) & $8.00^{\mathrm{b}}$ & $12.23^{\mathrm{a}}$ & $10.56^{\mathrm{ab}}$ & $10.23^{\mathrm{ab}}$ & 1.77 \\
Fecal N loss (g/day) & $2.34^{\mathrm{b}}$ & $3.87^{\mathrm{a}}$ & $3.26^{\mathrm{ab}}$ & $3.09^{\mathrm{ab}}$ & 0.53 \\
Urinary N loss (g/day) & 2.70 & 3.18 & 2.98 & 3.04 & 0.54 \\
Retained N (g/day) & $2.95^{\mathrm{b}}$ & $5.17^{\mathrm{a}}$ & $4.31^{\mathrm{ab}}$ & $4.10^{\mathrm{ab}}$ & 0.72 \\
N retention rate (\%) & $36.99^{\mathrm{c}}$ & $42.30^{\mathrm{a}}$ & $40.87^{\mathrm{ab}}$ & $40.01^{\mathrm{b}}$ & 1.07 \\
\hline
\end{tabular}

1) T1: TMR containing whole crop barley silage, T2: TMR containing rape silage,

T3: TMR containing rye silage, T4: TMR containing italian ryegrass silage.

2) Standard error of the mean.

a, b, c Means in a row with different superscripts are significantly different $(p<0.05)$.

지 첨가구의 $2.34 \mathrm{~g}$ 보다 유의하게 높은 배출량

을 보였다 $(\mathrm{p}<0.05)$. 뇨를 통한 질소 배출은

$2.70 \sim 3.18 \mathrm{~g}$ 의 범위로 나타났다.

질소축적량 및 축적율은 $2.95 \sim 5.17 \mathrm{~g}$ 과 36.9 $-42.3 \%$ 의 범위로 유채 사일리지 첨가구가 가 장 높게 나타났다 $(\mathrm{p}<0.05)$.

체내 질소 축적은 1 일 체중 $\mathrm{kg}$ 당 질소섭취량 이 최소 0.26 과 $0.24 \mathrm{~g}$ 이상 일 때 축적된다고 보고하였다(Boutouba 등, 1990; Nunez-Hernadez 등, 1989). 본 시험에는 질소 섭취량이 0.50 $0.76 \mathrm{~g}$ (1일/체중 $\mathrm{kg})$ 으로 나타나, 모든 구에서 질 소축적과 함께 증체가 이루어진 것으로 나타났 다.

일반적으로 질소 섭취량은 건물 섭취량에 비 례하며 (Kadzere와 Jingura, 1993), 질소 섭취량 이 증가할수록 분과 뇨로 배출되는 질소량도 증가한다(Osuagwuh와 Akinsoyinu, 1990). 본 시 험에서도 건물 섭취량이 높은 유채 사일리지 첨가구가 질소 섭취량이 높았고 분과 뇨로 손 실되는 질소량도 높게 나타났다. 또한, 질소축 적은 질소섭취량에 비례한다고 보고(Lallo, 1996)하여 질소섭취량이 높은 유채 사일리지
첨가구가 질소 축적율이 높게 나타난 것으로 사료된다.

\section{4. 혈액성상}

동계사료작물 사일리지 첨가 $\mathrm{TMR}$ 을 흑염소 에게 급여시 혈액성상에 미치는 영향은 Table 5 와 같다.

혈중 glucose 함량은 $54.3 \sim 57.8 \mathrm{mg} / \mathrm{d} \ell$ 의 범위 로 나타났으며, PUN (Plasma Urea Nitrogen)은 유채 사일리지 첨가구가 $16.0 \mathrm{mg} / \mathrm{d} \ell$ 으로 청보 리 사일리지 첨가구의 $14.5 \mathrm{mg} / \mathrm{dl}$ 보다 유의하 게 높은 수준이었다 $(\mathrm{p}<0.05)$. Total Cholesterol은 $65.6 \sim 67.4 \mathrm{mg} / \mathrm{d} l$ 의 범위로 나타났으며, $\mathrm{LDL}$ 과 $\mathrm{HDL}$ cholesterol은 각각 $11.1 \sim 13.1$ 과 $52.8 \sim 56.3 \mathrm{mg} / \mathrm{d} \ell$ 의 수준으로 시험구간 차이는 나타나지 않았다. Triglyceride 함량에서는 21 . $3 \sim 22.7 \mathrm{mg} / \mathrm{d} \ell$ 으로 시험구간 비슷한 수준으로 나타났다.

혈중 glucose는 탄수화물의 최종산물로서 체 조직에 에너지를 공급하는 역할을 하며, Singh 등 (1998)은 정상적인 산양의 혈중 glucose 함량 
Table 5. The effect of TMR containing different winter forage crops silage on plasma metabolites in Korean black goats

\begin{tabular}{lccccc}
\hline \multirow{2}{*}{ Items } & \multicolumn{4}{c}{ Treatments $^{1)}$} & \multirow{2}{*}{ SEM $^{2}$} \\
\cline { 2 - 5 } & T1 & T2 & T3 & T4 & \\
\hline Glucose $(\mathrm{mg} / \mathrm{d} \ell)$ & 54.39 & 57.89 & 56.56 & 57.44 & 5.86 \\
PUN $^{3)}(\mathrm{mg} / \mathrm{d} \ell)$ & $14.52^{\mathrm{b}}$ & $16.09^{\mathrm{a}}$ & $15.31^{\mathrm{ab}}$ & $14.82^{\mathrm{b}}$ & 0.50 \\
Total cholesterol $(\mathrm{mg} / \mathrm{d} \ell)$ & 66.17 & 67.11 & 67.45 & 65.67 & 12.00 \\
LDL cholesterol $(\mathrm{mg} / \mathrm{d} \ell)$ & 13.17 & 11.89 & 11.11 & 12.78 & 2.80 \\
HDL cholesterol $(\mathrm{mg} / \mathrm{d} \ell)$ & 53.00 & 55.22 & 56.34 & 52.89 & 9.81 \\
Triglyceride $(\mathrm{mg} / \mathrm{d} \ell)$ & 21.39 & 22.56 & 22.78 & 21.56 & 6.11 \\
\hline
\end{tabular}

1) T1: TMR containing whole crop barley silage, T2: TMR containing rape silage,

T3: TMR containing rye silage, T4: TMR containing italian ryegrass silage.

2) Standard error of the mean; ${ }^{3)}$ Plasma urea nitrogen.

a, b Means in a row with different superscripts are significantly different $(\mathrm{p}<0.05)$.

이 $45 \sim 60 \mathrm{mg} / \mathrm{d} \ell$ 라고 보고하였다. 본 시험에서 는 시험구간 뚜렷한 경향은 나타나지 않았지만 $54.4 \sim 57.9 \mathrm{mg} / \mathrm{d} \ell$ 의 범위로 나타나 모든 시험구 간에서 흑염소 체내에 정상적인 에너지 공급이 이루어지고 있음을 알 수 있었으며, 또한 체내 단백질 대사의 지표(Turner 등, 2005)가 되는 혈중 PUN은 본 시험에서 질소섭취 및 축적율 이 높았던(Table 4) 유채 사일리지 첨가구가 높은 혈중 PUN을 보여 유채 사일리지 첨가는 체내 단백질 대사를 개선함을 알 수 있었다.

이상의 결과를 종합하면, 유채 사일리지 첨 가구가 영양소 소화율에서 청보리 사일리지 첨 가구 보다 다소 낮았지만, 영양소 및 가소화 영양소 섭취량, 일당증체량 및 질소축적율 등 에서 우수한 것으로 나타나, 동계사료자원 중 유채 사일리지 첨가는 흑염소의 생산성을 향상 시키는 것으로 사료된다.

$$
\text { V. 요 약 }
$$

본 연구는 동계사료작물 사일리지를 첨가한
$\mathrm{TMR}$ 을 급여하였을 때, 흑염소의 사료 섭취량, 일당 증체량, 영양소 소화율 및 질소 축적율에 미치는 영향을 조사하여 흑염소에 대한 동계사 료작물의 사료가치 평가의 자료로 이용하고자 실시하였다. 공시가축은 흑염소 12 두(송)를 4 처리구(T1: 청보리 사일리지 첨가구, $\mathrm{T} 2$ : 유채 사일리지 첨가구, $\mathrm{T} 3$ : 호밀 사일리지 첨가구 및 $\mathrm{T} 4$ : 이탈리안 라이그라스 사일리지 첨가구) 로 나누어 처리구당 3 두씩 개체별 대사케이지 에 라틴방각법으로 실시하였으며 그 결과는 다 음과 같다. 1 일 두당 건물, 유기물 및 조단백질 섭취량은 유채 사일리지 첨가구가 가장 높았 고, 청보리 사일리지 첨가구가 가장 낮았다 $(\mathrm{p}<0.05)$. 조단백질 및 $\mathrm{ADF}$ 가소화 섭취량 또 한 유채 사일리지 첨가구가 가장 높았다 $(\mathrm{p}<$ 0.05). 1 일 증체량은 유채 사일리지 첨가구, 호 밀 사일리지 첨가구 및 이탈리안 라이그라스 사일리지 첨가구가 청보리 사일리지 첨가구 보 다 유의하게 높았다 $(\mathrm{p}<0.05)$. 건물, 조단백질 및 섬유소 소화율은 청보리 사일리지 첨가구가 가장 높았으며, 유채 사일리지 첨가구가 유의 
하게 낮았다 $(\mathrm{p}<0.05)$. 질소섭취량과 질소축적율 은 유채 사일리지 첨가구가 유의하게 높았으 며, 청보리 사일리지 첨가구가 가장 낮았다 $(\mathrm{p}<$ 0.05). 이러한 결과를 종합적으로 고려할 때 동 계사료작물 중 유채 사일리지 첨가시 사료 섭 취량 및 질소 축적율 증가로 인해 흑염소의 생 산성이 높은 것으로 나타났다.

\section{V. 인 용 문 헌}

1. 김광국, 조익환, 황보순. $2007 \mathrm{a}$. 총체 보리사일리 지를 첨가한 유기 TMR 급여가 흑염소의 사료섭 취량, 영양소 소화율 및 혈액성상에 미치는 영 향. 한국유기농업학회지. 15(4):413-424.

2. 김맹중, 최기준, 육완방, 임영철, 윤세형, 김종근, 박형수, 서 성. 2007b. 논에서 이탈리안 라이그라 스의 파종방법이 월동, 건물수량 및 사료가치에 미치는 영향. 한초지. 27(4):269-274.

3. 김원호, 서 성. 2006. 총체보리를 중심으로 한 동 계사료작물의 재배 및 이용기술. 한국초지학회 2006년 학술 심포지엄. pp. 37-57.

4. 송해범, 조익환, 전문장, 박용구, 홍기창, 박노찬, 도재철, 임해수. 1999. 염소 사육농가의 소득향상 방안에 관한 연구. 농림부.

5. 이현준, 김현섭, 기광석, 정하연, 백광수, 김준식, 조광근, 조재순, 이홍구, 우정희, 최윤재. 2003. 청예사료작물과 볏짚 위주의 완전배합발효사료 급여가 Holstein 착유우의 생산성에 미치는 영향. 동물자원지. 45(1):69-78.

6. 이현준, 조광근, 김원호, 김현섭, 김준식, 강승하, 강상기, 우정희, 이홍구, 최윤재. 2002. 청예사료 작물과 볏짚을 이용한 완전배합발효사료의 제조 와 영양적 가치. 동물자원지. 44(1):75-86.

7. 정기웅, 조익환, 황보순, 이성훈, 송해범. 2008. 사료급여체계가 재래종 및 교잡종 흑염소의 영 양소 이용율, 질소축적 및 혈액성상에 미치는 영 향. 초지조사료지. 28(4):341-350.

8. 조익환, 윤용범, 박웅렬, 황보순, 이성훈, 이주삼. 2008. 답리작으로 호밀과 헤어리베치의 단, 혼파 재배 시 우분뇨 및 화학비료의 시용에 따른 생 산성 평가. 초지조사료지. 28(4):323-330.
9. 황보순, 최순호, 김상우, 김원호, 손동수, 조익환. 2008. 청보리 사일리지 급여 시에 농후사료 급여 수준이 육성기 흑염소의 발육과 육질에 미치는 영향. 동물자원지. 50(4):527-534.

10. AOAC. 1995. Official Methods of Analysis. 16th ed. Association of Official Analytical Chemists. Washington, DC.

11. Barnes, R.R., D.A. Miller and C.J. Nelson. 1995. Forages. 5th ed. Iowa State University Press, Ames, Iowa.

12. Boutouba, A., J.L. Holechek, M.L. Galyean, G. Nunez-Hernadez and M. Wallace, Cardenas. 1990. Influence of two native shrubs on goat nitrogen status. J. Range Manage. 43:530-534.

13. Huston, J. E., B.S. Rector, W.C. Ellis and M. L. Allen. 1986. Dynamics of digestion in cattle, sheep, goats and deer. J. Anim. Sci. 62:208-215.

14. Islam, M., H. Abe, Y. Hayashi, F. Terada. 2000. Effects of feeding Italian ryegrass with corn on rumen environment, nutrient digestibility, methane emission, and energy and nitrogen utilization at two intake levels by goats. Small Rumin. Res. 38: 165-174.

15. Kadzere, C.T., Jingura, R. 1993. Digestibility and nitrogen balance in goats given different levels of crushed whole soybeans. Small Rumin. Res. 10: 175-180.

16. Lallo, C.H.O. 1996. Feed intake and nitrogen utilisation by growing goats fed by-product based diets of different protein and energy levels. Small Rumin. Res. 22: pp. 193-204.

17. Nocek, J.E., Steele, R.L., Braund, D.G. 1985. Effect of mixed ration nutrient density on milk of cows transferred from high production group. J. Dairy Sci. 68:133.

18. NRC. 1981. Nutrient requirements of goats, National academy of sciences - National reserch council, Washington DC.

19. Nunez-Hernadez, G., J.L. Holecheck, J.D. Wallace, M.L. Galyean, A. Tempo, R. Valdez and M. Cardenas. 1989. Influence of native shrubs on nutritional status of goats: nitrogen retention. J. 
Range Manage. 42:228-232.

20. Osuagwuh, A.I.A., Akinsoyinu, A.O. 1990. Efficiency of nitrogen utilization by pregnant West African dwarf goats fed various levels of crude protein in the diet. Small Rumin. Res. 3: pp. 363-371.

21. SAS. 2000. SAS/STAT ${ }^{\circledR}$ User's guide (Release 8.1 ed.). Statistics, SAS Inst, Inc., Cary, NC.

22. Singh, U.P., Lodhi, G.N., Mahanta, S.K., Pachuri, V.C., 1998. Effect of legume tree leaves on feed intake and blood constituents in growing goats. In: Proceedings of the Golden Jubliee Seminar on Sheep, Goats and Rabbit Production and Utilization, CSWRI-GIRG-Central Wool Development Board, Jaipur, pp. 21-26.

23. Steel, R.G.D. and Torrie, J.H. 1980. Principles and procedures of statistics: A biometrical approach (2nd Ed.). McGraw-Hill Bok Co., New York.

24. Turner, K.E., S. Wildeus, J.R. Collins. 2005. Intake, performance, and blood parameters in young goats offered high forage diets of lespedeza or alfalfa hay. Small Rumin. Res. 59:15-23.

25. Van Soest, P.J. 1994. Nutritional Ecology of the Ruminant (2nd eds.). Cornell University Press, Ithaca, NY.

26. Van Soest, P.J., Robertson, J.B. and Lewis, B.A. 1991. Methods for dietary fiber, neutral detergent fiber, and non-starch polysaccharide in relation to animal nutrition. J. Dairy Sci. 74:3583-3597.

(접수일: 2009년 10월 20일, 수정일 1차: 2009년 11 월 13일, 수정일 2차: 2009년 11월 30일, 게재확정일: 2009년 12월 10일) 